\title{
Analisis Faktor-Faktor yang Mempengaruhi Permintaan Daging Ayam Broiler Pada Rumah Tangga Di Kabupaten Demak
}

\author{
Febrianti Rahmadani, Kustopo Budiraharjo dan Hery Setiyawan ${ }^{1}$
}

\author{
Program Studi Agribisnis, Fakultas Peternakan dan Pertanian, Universitas Diponegoro, \\ Tembalang, Semarang 50275 - Indonesia \\ Email : febriantirahmadani08@gmail.com
}

\begin{abstract}
ABSTRAK
Penelitian bertujuan untuk mengetahui faktor-faktor yang mempengaruhi permintaan daging ayam broiler dan mengetahui jumlah permintaan rumah tangga terhadap daging ayam broiler. Lokasi penelitian secara purposive, metode yang digunakan adalah metode survei, pengambilan sampel secara Quota Sampling, dan penentuan responden dengan metode Multistage Random Sampling yang terdiri dari 90 responden dari 3 Kecamatan di Kabupaten Demak. Analisis data menggunakan rumus Regresi Linier Berganda dalam fungsi logaritma (Ln). Variabel yang diamati dalam penelitian ini adalah harga daging ayam broiler $\left(X_{1}\right)$, harga ayam kampung $\left(X_{2}\right)$, pendapatan konsumen $\left(X_{3}\right)$, jumlah anggota keluarga $\left(X_{4}\right)$ dan selera konsumen $\left(X_{5}\right)$. Hasil analisis menunjukkan bahwa variabel-variabel bebas yang diamati secara bersamasama berpengaruh nyata terhadap permintaan daging ayam broiler. Secara parsial harga ayam kampung, jumlah anggota keluarga dan selera konsumen berpengaruh nyata terhadap permintaan daging ayam broiler, sedangkang harga ayam broiler dan pendapatan tidak berpengaruh nyata terhadap permintaan daging ayam broiler.
\end{abstract}

Kata kunci : Ayam broiler, Faktor permintaan, Rumah tangga

\section{ABSTRACT}

The aimed of this research is to know the factors that influence the demand of broiler chicken and to know the number of household demand for broiler meat. The research location is purposive, the method used is survey method, sampling by Quota Sampling, and respondent determination by Multistage Random Sampling method consisting of 90 respondents from 3 District in Demak District. Data analysis using Multiple Linear Regression formula in logarithmic function (Ln). The variables observed in this research are broiler chicken price (X1), chicken price (X2), consumer income (X3), number of family member (X4) and consumer appetite (X5). The results showed that the observed independent variables significantly affect the demand of broiler chicken meat. Partially the price of chicken, the number of family members and consumer tastes significantly affect the demand of broiler chicken meat, broiler prices and broiler prices did not significantly affect the demand of broiler chicken meat.

Keywords : broiler chicken, demand factor, household

\section{PENDAHULUAN}

Sektor pertanian merupakan sektor yang sangat penting dalam pembangunan ekonomi bangsa Indonesia. Sektor pertanian tidak hanya identik dengan usaha dalam hal bercocok tanam, dalam arti luas pertanian mencakup 5 subsektor yaitu subsektor tanaman pangan, perkebunan, kehutanan, peternakan dan perikanan. Salah satu subsektor pertanian yang mempunyai peranan cukup penting adalah subsektor peternakan karena sektor peternakan merupakan salah satu penghasil pangan bagi masyarakat khususnya dalam pemenuhan protein hewani (Pranata et al., 2013).

Daging ayam merupakan sumber bahan pangan hewani yang mengandung gizi cukup tinggi berupa protein dan energi. Ayam ras pedaging merupakan salah satu komoditas yang tergolong paling populer dalam dunia agribisnis peternakan di Indonesia. Ayam ras pedaging merupakan usaha peternakan yang 
Agrisaintifika

berkembang paling menakjubkan. Usaha ayam pedaging cukup prospektif karena selera masyarakat terhadap cita rasa ayam sangat tinggi disemua kalangan. Nilai keuntungan yang diperoleh juga cukup tinggi jika dikelola dengan efisien (Setyono dan Ulfah, 2011). Daging ayam memiliki kandungan protein sebesar 18,20 gram, lemak sebesar 25 gram, serta memiliki kalori sebesar 404 Kkal per 100 gram daging ayam. Daging ayam merupakan sumber protein hewani yang berkualitas tinggi, mengandung asam amino essensial yang lengkap dan asam lemak tidak jenuh yang tinggi ( Direktorat Gizi Departemen Kesehatan, 2010).

Kabupaten Demak menempati peringkat ke tiga dalam memproduksi daging ayam broiler se-Jawa Tengah (BPS Jawa Tengah, 2015). Permintaan daging ayam broiler di Kabupaten Demak dari tahun ke tahun mengalami peningkatan yang menyebabkan permintaan semakin meningkat. Tahun 2013, produksi daging ayam broiler mencapai jumlah $5.616 .200 \mathrm{~kg}$, tahun 2014 berjumlah $7.519 .800 \mathrm{~kg}$, tahun 2015 berjumlah $8.357 .600 \mathrm{~kg}$ dan tahun 2016 berjumlah 10.712.250 kg (BPS Kabupaten Demak, 2017). Oleh karena itu perlu adanya penelitian mengenai faktor-faktor yang berpengaruh terhadap permintaan daging ayam broiler pada rumah tangga di Kabupaten Demak. Tujuan dari penelitian ini adalah untuk mengetahui jumlah permintaan rumah tangga terhadap daging ayam broiler dan mengetahui faktor-faktor yang berpengaruh terhadap permintaan daging ayam broiler di Kabupaten Demak.

\section{METODE}

\section{Waktu dan Tempat Pelaksanaan}

Penelitian dilaksanakan mulai bulan November- Desember 2017 yang berlokasi di Kabupaten Demak. Pemilihan lokasi dilakukan dengan sengaja (puposive) yaitu penentuan lokasi secara sengaja dengan pertimbangan bahwa Kabupaten Demak menempati peringkat ketiga produksi daging ayam broiler di Jawa Tengah.

\section{Metode Penelitian dan Pengambilan Sampel}

Metode yang digunakan adalah metode survei. Metode pengambilan sampel yaitu secara Quota Sampling sebanyak 30 orang pada masing-masing Kecamatan. Hal ini sesuai dengan pendapat Mahmud (2011) yang menyatakan bahwa penelitian regresi yang menggunakan analisis data statistik, dalam populasi besar ukuran sampel paling minimum yaitu 30 . Total 90 responden dari 3 Kecamatan di Kabupaten Demak dengan pertimbangan produksi daging ayam broiler tertinggi yaitu Kecamatan Sayung, tertinggi kedua yaitu Kecamatan Demak dan tertinggi ketiga Kecamatan Gajah. penentuan responden selanjutnya dilakukan dengan metode multistage random sampling.

Jenis Data dan Metode Pengumpulan Data

Data yang digunakan terdiri dari data primer yang diperoleh dari wawancara dengan bantuan kuesioner dan data sekunder diperoleh dari studi pustaka dan sumber lain yang mendukung.

\section{Metode Analisis Data}

Metode analisis yang digunakan dengan analisis deskriptif dan kuantitatif. Analisis kuantitatif dengan persamaan regresi linier berganda. Sebelum melakukan analisis data diuji sesuai asumsi klasik yaitu normalitas, multikolinearitas, autokorelasi dan heteroskedastisitas.

Analisis regresi linier berganda digunakan untuk mengetahui pengaruh beberapa variabel yang meliputi harga daging ayam broiler, harga ayam kampung, pendapatan konsumen, jumlah anggota keluarga dan selera konsumen. Program yang digunakan adalah SPSS 16 for Windows. Data yang dianalisis dengan regresi linier berganda di tranformasi ke dalam bentuk logaritma yang digunakan untuk mengetahui elastisitas permintaan. Menurut Ghozali (2009) menyatakan bahwa untuk mengetahui elastisitas permintaan, persamaan regresi linier dapat 
Agrisaintifika

Jurnal Ilmu-Ilmu Pertanian

Vol. 2, No. 1, 2018

Rahmadani, et al. 2018

ditranformasikan ke dalam bentuk logaritma.

Berikut adalah persamaan regresi linier berganda :

$\ln Y=\alpha+\beta 1 \ln X_{1}+\beta 2 \ln X_{2}+\beta 3 \ln X_{3}+\beta 4$ $\ln X_{4}+\beta 5 \ln X_{5}+e$

$Y$ =Jumlah Permintaan Daging Ayam ( $\mathrm{kg} /$ minggu)

$\mathrm{a}=$ Alfa

$\beta=$ Koefisien Regresi

$\mathrm{e}=$ Error

$\mathrm{X}_{1}=$ Harga daging ayam $(\mathrm{Rp} / \mathrm{kg})$

$\mathrm{X}_{2}=$ Harga daging ayam kampung $(\mathrm{Rp} / \mathrm{kg})$

$\mathrm{X}_{3}=$ Jumlah anggota keluarga (jiwa)

$\mathrm{X}_{4}=$ Pendapatan konsumen (Rp/bln)

$\mathrm{X}_{5}=$ Selera konsumen (skor)

Uji Koefisien Determinasi $\left(R^{2}\right)$ untuk mengetahui besarnya persentase pengaruh variabel independen terhadap variabel dependen. Uji $\mathrm{F}$ untuk mengetahui ada tidaknya perbedaan rata-rata pengaruh variabel independen terhadap variabel dependen secara serempak. Uji $T$ untuk mengetahui pengaruh variabel independen terhadap variabel dependen secara parsial.

\section{HASIL DAN PEMABAHASAN}

\section{Keadaan Umum Kabupaten Demak}

Demak sebagai salah satu Kabupaten di Jawa Tengah yang terletak di antara $6^{\circ} 43^{\prime} 26^{\prime \prime}$ - 709'43" Lintang Selatan dan 110 48'47" Bujur Timur. Secara administratif Kabupaten Demak yang memiliki luas $89.743 \mathrm{Ha}$ yang terdiri dari $51.799 \mathrm{Ha}(57,72 \%)$ lahan pertanian sawah $37.944 \mathrm{Ha}(42,29 \%)$ lahan pertanian bukan sawah (Badan Pusat Statistik Kabupaten Demak, 2016). Kabupaten Demak terbagi dalam 14 Kecamatan yang terdiri dari 243 Desa dan 6 Kelurahan. Kecamatan terluas adalah Kecamatan Wedung yaitu $9.876 \mathrm{Ha}$ dan yang paling kecil adalah Kecamatan Kebonangung yaitu 4.199 Ha.Wilayah Kabupaten Demak adapun batas administasinya meliputi :

- Sebelah Utara : Kabupaten Jepara dan Laut Jawa

- Sebelah Timur : Kabupaten Kudus dan Kabupaten Grobogan
- Sebelah Selatan : Kabupaten Grobogan dan Kabupaten Semarang

- Sebelah Barat : : Kota Semarang

\section{Karakteristik Responden Jenis Kelamin}

Berdasarkan hasil analisis deskriptif, karakteristik pada jenis kelamin yang dominan diambil yaitu responden perempuan karena dalam suatu rumah tangga yang menentukan kebutuhan sehari-hari adalah ibu rumah tangga.

Umur

Umur responden yang diambil yaitu pada usia orang dewasa yang biasanya $>20$ tahun. Berdasarkan hasil penelitian, diketahui bahwa responden terbanyak yaitu pada usia 40-49 tahun dengan persentase $41,1 \%$ dan yang sedikit pada usia 60-69 tahun dnegan persentase $5,5 \%$. Usia adalah salah satu faktor mempengaruhi permintaan barang.

\section{Pendidikan}

Pendidikan merupakan salah satu kebutuhan dasar manusia yang diperlukan untuk menjalani kehidupannya agar lebih baik. Semakin tinggi pendidikan seseorang maka akan semakin baik kualitas hidupnya. Berdasarkan hasil penelitian diketahui bahwa responden yang paling banyak yaitu lulusan SMA sebesar 39,9\%.

\section{Pekerjaan}

Pekerjaan (mata pencaharian) merupakan aktifitas manusia untuk memperoleh taraf hidup yang layak dengan menghasilkan pendapatan untuk menunjang kebutuhan sehari-hari. Berdasrakan hasil penelitian diketahui bahwa responden yang paling banyak yaitu pada ibu rumah tangga dengan persentase $35,6 \%$ karena pada dasarnya yang memiliki peran besar dalam menentukan kebutuhan sehari-hari adalah ibu rumah tangga.

\section{Uji Asumsi Klasik}

Hasil uji normalitas menunjukkan bahwa variabel yang diamati berdistribusi normal karena nilai asymp. Sig (2-tailed) sebesar 0,685 yang artinya lebih besar dari signifikansi 0,05 . 
Agrisaintifika

Hasil uji menunjukkan bahwa data yang diuji tidak ada multikolinearitas karena nilai VIF tidak ada diatas 10 (berkisar antara 1,016-1,204) dan nilai tolerance tidak ada yang dibawah 0,10 (berkisar antar 0,8310,984).

Hasil uji heteroskedastisitas
menunjukkan bahwa tidak terjadi heteroskedastisitas karena penyebaran titiktitik berada pada diatas dan dibawah angka 0 serta tidak membentuk pola. Sedangkan uji autokorelasi menunjukkan bahwa tidak terjadi korelasi karena nilai DW > DU dan (4-DW) > DU atau berada antara 1,954 $>1,775$ dan $2,046>1,775$.

\section{Uji Koefisien Determinasi $\left(\mathbf{R}^{\mathbf{2}}\right)$}

Berdasarkan hasil uji $R^{2}$ menunjukkan bahwa nilai $R$ square sebesar 0,378 . Hal ini menunjukkan bahwa 37,8 \% permintaan daging ayam broiler di Kabupaten Demak dapat dijelaskan oleh variabel harga ayam broiler, harga ayam kampung, pendapatan konsumen, selera konsumen dan jumlang anggota keluarga. Sedangkan sisanya 62,2
$\%$ dijelaskan oleh variabel lain yang tidak diteliti.

\section{Uji F}

Berdasarkan hasil uji $\mathrm{F}$ diketahui bahwa nilai signifikansi sebesar $0,000<0,05$. Hal ini menunjukkan bahwa variabel-variabel bebas yang diamati yaitu harga ayam boriler, harga ayam kampung, pendapatan keluarga, jumlah anggota keluarga dan selera konsumen secara bersama-sama berpengaruh nyata terhadap permintaan daging ayam broiler.

Uji T

Berdasarkan hasil uji T diketahui bahwa nilai signifikansi variabel harga ayam broiler dan pendapatan sebesar 0,760 dan 0,307 $(>0,05)$ yang artinya harga ayam broiler dan pendapatan tidak mempengaruhi permintaan daging ayam broiler. Sedangkan variabel harga ayam kampung, jumlah anggota keluarga dan selera konsumen nilai signifikannya yaitu $0,003,0,000$ dan 0,000 $(<0,05)$ yang artinya harga ayam kampung, jumlah anggota keluarga dan selera konsumen berpengaruh terhadap permintaan daging ayam broiler.

Tabel 1. Hasil Analisis

\begin{tabular}{llll}
\hline \hline Variabel & Koefisien Regresi & $\mathrm{T}$ & Sig. \\
\hline Konstanta & 16,498 & 1,561 & 0,122 \\
Harga daging ayam broiler & $-0,259$ & $-0,306$ & 0,760 \\
Harga ayam kampung & $-1,667$ & $-3,015$ & 0,003 \\
Pendapatan & 0,118 & 1,027 & 0,307 \\
Jumlah anggota keluarga & 0,762 & 3,662 & 0,000 \\
Selera konsumen & 1,387 & 4,739 & 0,000 \\
\hline
\end{tabular}

Sumber : Data Primer Terolah, 2018.

Keterangan : variabel dalam bentuk logaritma (Ln)

Berdasarkan Tabel 1, menunjukkan bahwa persamaan regresi linier berganda sebagai berikut :

$\operatorname{Ln} Y=16,498-0,259 \ln X_{1}-1,667 \ln X_{2}+$ $0,118 \ln X_{3}+0,762 \ln X_{4}+1,387 \ln X_{5}+e$. Dari persamaan tersebut dapat dijelaskan bahwa nilai konstanta sebesar 16,498 yang artinya jika terjadi perubahan pada harga daging ayam broiler, harga ayam kampung, pendapatan keluarga, jumlah anggota keluarga dan selera konsumen maka permintaan daging ayam broiler di Kabupaten Demak meningkat sebesar 16,498 . Nilai $\beta 1$ harga daging ayam broiler sebesar $-0,259$ yang artinya bahwa jika terjadi kenaikan $1 \%$ harga daging ayam broiler maka permintaan daging ayam broiler menurun sebesar -0,259. Koefisien bernilai negatif artinya terjadi hubungan negatif antara harga ayam broiler dengan permintaan daging ayam broiler. Nilai ß2 harga ayam kampung sebesar $-1,667$ yang artinya bahwa jika terjadi kenaikan $1 \%$ 
Agrisaintifika

harga ayam kampung maka permintaan daging ayam broiler menurun sebesar -1,667. Koefisien bernilai negatif artinya terjadi hubungan negatif antara harga ayam kampung dengan permintaan daging ayam broiler. Menurut Salvatore (2001) menyatakan bahwa barang substitusi nilai koefisien regresinya positif, dengan demikian hasil penelitian ini menunjukkan bahwa daging ayam broiler bukan merupakan substitusi daging ayam kampung. Hasil penelitian di Kabupaten Demak ini berbeda dengan hasil penelitian di Kabupaten Aceh Timur, Ridha (2017) yang menyatakan bahwa koefisien regresi harga ayam kampung sebesar 1,608. Tanda positif menunjukkan pengaruh yang searah antara harga ayam kampung dengan permintaan daging ayam broiler. Hal ini menunjukkan bahwa daging broiler dapat menjadi substitusi bagi ayam kampung, karena harga ayam kampung di Kabupaten Aceh Timur mencapai 2 kali lipat dari harga ayam broiler.Nilai $\beta 3$ pendapatan konsumen sebesar 0,118 yang artinya bahwa jika terjadi kenaikan $1 \%$ pendapatan konsumen maka permintaan daging ayam broiler meningkat sebesar 0,118 . Nilai $\beta 4$ jumlah anggota keluarga sebesar 0,762 yang artinya bahwa terjadi kenaikan $1 \%$ jumlah anggota keluarga maka permintaan daging ayam broiler meningkat sebesar 0,762 . Nilai $\beta 5$ selera konsumen sebesar 1,387 yang artinya bahwa terjadi kenaikan $1 \%$ selera konsumen maka permintaan daging ayam broiler meningkat sebesar 1,387.

\section{Elastisitas Harga}

Berdasarkan tabel 2, dapat diketahui bahwa elastisitas harga beras sebesar -0,259 yang artinya jika harga ayam broiler meningkat $1 \%$ maka permintaan daging ayam broiler menurun sebesar 0,259\%. Elastisitas harga ayam broiler nilainya kurang dari 1 yang artinya bersifat inelastis sehingga daging ayam termasuk kategori barang normal. Hal ini sesuai dengan pendapat
Salvatore (2001) yang menyatakan bahwa koefisien elastisitas harga merupakan perbandingan antara persentase jumlah komoditi yang diminta per unit waktu dengan persentase perubahan harga tertentu dari komoditas tersebut. Permintaan akan elastis bila nilai $\mathrm{Ei}>1$, inelastis $\mathrm{Ei}<1$ dan elastis uniter $\mathrm{E}=1$.

\section{Elastisitas Silang}

Berdasarkan tabel 2, dapat diketahui bahwa elastisitas silang harga ayam kampung sebesar $-1,667$ yang artinya jika harga ayam kampung naik $1 \%$ maka permintaan daging ayam broiler akan menurun $1,667 \%$. Koefisien regresi bernilai negatif menunjukkan bahwa ayam kampung bukan satu-satunya barang substitusi ayam broiler adapun seperti contohnya ikan laut, tahu dan tempe. Hal ini sesuai dengan pendapat Salvatore (2001) yang menyatakan bahwa apabila nilai elastisitas silang yang di dapat bernilai negatif maka barang $X$ dan $Y$ merupakan barang komplementer, sedangkan jika nilai elastisitas silang positif maka barang $X$ dan $Y$ merupakan barang substitusi.

\section{Elastisitas Pendapatan}

Berdasarkan tabel 2, dapat diketahui bahwa elastisitas pendapatan sebesar 0,118 artinya jika pendapatan naik sebesar $1 \%$ maka permintaan daging ayam broiler meningkat sebesar $0,118 \%$. Nilai elastisitas pendapatan bersifat inelastis karena $(\mathrm{Ei}<1)$ dan bertanda positif yang merupakan daging ayam broiler merupakan barang normal. Hal ini sesuai dengan pendapat Suparmoko (2011) yang menyatakan bahwa nilai elastisitas pendapatan $(\mathrm{Ei}<0)$ maka barang tersebut merupakan barang inferior, elastisitas pendapatan bernilai antara 0 sampai 1 maka barang normal dan elastisitas pendapatan bernilai (Ei>1) maka barang mewah. 
Tabel 2. Hail Uji Elastisitas

\begin{tabular}{llll}
\hline \hline \multirow{2}{*}{ Variabel } & \multicolumn{3}{c}{ Nilai Elastisitas } \\
\cline { 2 - 4 } & Harga (Ep) & Silang (Ec) & Pendapatan (Ei) \\
\hline Harga ayam broiler & $-0,259$ & $-1,667$ & \\
Harga ayam kampung & & & 0,118 \\
Pendapatan konsumen & & & \\
\hline
\end{tabular}

Sumber : Data Primer Terolah, 2018.

\section{KESIMPULAN}

1. Perkembangan harga daging ayam broiler tidak stabil. Pada tahun 20162018 mengalami naik turun. Sedangkan perkembangan permintaan ayam broiler menurut BPS dari tahun 2012-2016 mengalami peningkatan.

2. Secara serempak faktor-faktor yang mempengaruhi jumlah permintaan daging ayam broiler (harga ayam broiler, harga ayam kampung, pendapatan, jumlah anggota keluarga dan selera konsumen) memberi pengaruh yang nyata terhadap jumlah permintaan daging ayam broiler. Hal ini disimpulkan berdasarkan nilai signifikan sebesar $0,000<0,05$ sehingga $\mathrm{H}_{0}$ ditolak dan $\mathrm{H}_{1}$ diterima yang artinya variabel-variabel bebas secara bersama-sama berpengaruh terhadap permintaan daging ayam broiler.

3. Secara parsial harga ayam kampung, jumlah anggota keluarga dan selera konsumen berpengaruh nyata terhadap permintaan daging ayam broiler, sedangkan harga ayam broiler dan pendapatan tidak berpengaruh nyata terhadap permintaan daging ayam broiler.

4. Elastisitas permintaan daging ayam broiler bersifat inelastis; elastisitas silang permintaan harga daging ayam broiler terhadap harga daging ayam kampung bersifat elastis namun bukan merupakan barang substitusi; elastisistas pendapatan bersifat inelastis.

\section{DAFTAR PUSTAKA}

Badan Pusat Statistik. 2015. Provinsi Jawa Tengah Dalam Angka 2015. Jawa Tengah.

Badan Pusat Statistik. 2017. Kabupaten Demak Dalam Angka 2017. Demak.

Direktorat Gizi Departemen Kesehatan. 2010. Daftar Komposisi Bahan Makanan. Penerbit Bhratara, Jakarta.

Ghozali, I. 2009. Ekonometrika. Teori Konsep dan Aplikasi dengan SPSS 17. Badan Penerbit Universitas Diponegoro, Semarang.

Mahmud. 2011. Metode Penelitian Pendidikan. Pustaka Setia, Bandung.

Pranata, E., Salmiah dan Hutajulu. 2013. Analisis permintaan ayam broiler/pedaging di Kota Medan. Jurnal Agribisnis. 2 (9) : 2.

Ridha, A. 2017. Beberapa faktor yang mempengaruhi permintaan daging ayam broiler pada rumah tangga di Kecamatan Idi Rayeuk Kabupaten Aceh Timur. Jurnal Ekonomi. 17(1) : 27.

Salvatore, D. 2011. Teori Ekonomi Mikro. Erlangga, Jakarta.

Setyono, D.J dan Ulfah, M. 2011. 7 Jurus Sukses Menjadi Peternak Ayam Ras Pedaging. Penebar Swadaya, Jakarta.

Suparmoko, S. 2011. Pengantar Teori Mikroekonomi Edisi Ketiga. BPFE, Yogyakarta. 